\title{
PENINGKATAN PEMAHAMAN PEMBELAJARAN BAHASA INDONESIA BERBASIS TEKS DALAM KURIKULUM 2013 MELALUI SIARAN PEMBINAAN BAHASA INDONESIA DI RADIO REPUBLIK INDONESIA SURAKARTA
}

\author{
Laili Etika Rahmawati, Main Sufanti, Markhamah, dan Abdul Ngalim \\ Program Studi Pendidikan Bahasa dan Sastra Indonesia \\ Fakultas Keguruan dan Ilmu Pendidikan \\ Universitas Muhammadiyah Surakarta \\ laili_etikarahmawati.pbsidums@yahoo.com
}

\begin{abstract}
The aims of service on social through the on air broadcast of RRI Surakarta were to: (1) improve the understanding of teachers of Bahasa Indonesia toward the Bahasa Indonesia learning program based on texts; (2) enrich the knowledge of the listeners, especially for the students in which the learning of bahasa Indonesia based on the curriculum 2013; (3) create the close work relation of institution between the Muhammadiyah University of Surakarta and the government instituion i.e. Radio of Indonesian Republic of Surakarta. The soacial service was conducted in RRI of Surakarta, in the form of lecturing in an on-air broadcast, based on the paper which had been prepared before. The on-air broadcast activities were conducted by the recording before broadcasted. The recording process used the facilities in RRI of Surakarta guided by workers of RRI of Surakarta, both the responsibility and the recording process. The activities were conducted by on-air broaadcast. Every time the on-air broadcast was conducted by the speaker in which the topics were varies but, they were still on one theme. The on-air broadcast theme on the next three month is "The Improvement of Understanding the Learning of Bahasa Indonesia based on Texts of the Curriculum 2013 through the guiding on-air broadcast of Bahasa Indonesia in RRI of Surakarta”. The six times on-air broadcast activities which planned for three months, could be conducted six times of the new on-air broadcast.
\end{abstract}

Kata kunci: pembelajaran, bahasa Indonesia, teks, siaran, RRI Surakarta

\section{PENDAHULUAN}

Perkembangan paradigma pembelajaran memberikan dampak yang signifikan terhadap aturan pendidikan. Kurikulum menjadi salah satu komponen penting dalam penyelenggaraan pendidikan. Kurikulum 2013 menyadari peran penting bahasa sebagai wahana untuk menyebarkan pengetahuan dari seseorang ke orang-orang lain. Penerima akan dapat menyerap pengetahuan yang disebarkan tersebut hanya bila menguasai bahasa yang dipergunakan dengan baik. Hal yang sama juga berlaku pada pengirim pesan. Ketidaksempurnaan 
pemahaman bahasa akan menyebabkan terjadinya distorsi dalam proses pemahaman terhadap pengetahuan. Apapun yang akan disampaikan pendidik kepada peserta didiknya hanya akan dapat dipahami dengan baik apabila bahasa yang digunakan dapat dipahami dengan baik oleh kedua belah pihak.

Kurikulum 2013 menempatkan bahasa Indonesia sebagai penghela mata pelajaran lain, untuk itu mata pelajaran Bahasa Indonesia harus berada di depan semua mata pelajaran lain. Apabila peserta didik tidak menguasai mata pelajaran tertentu harus dipastikan bahwa yang tidak dikuasainya adalah substansi mata pelajaran tersebut, bukan karena kelemahan penguasaan bahasa pengantar yang digunakan.

Sejalan dengan peran bahasa Indonesia di atas, maka pelaksanaan pembelajaran Bahasa Indonesia di sekolah diterapkan dengan pembelajaran berbasis teks, baik lisan maupun tulis. Di dalam pendekatan pembelajaran Bahasa Indonesia berbasis teks dijelaskan tentang berbagai cara penyajian pengetahuan dengan berbagai macam jenis teks. Pemahaman terhadap jenis, kaidah, dan konteks suatu teks ditekankan sehingga memudahkan peserta didik menangkap makna yang terkandung dalam suatu teks maupun menyajikan gagasan dalam bentuk teks yang sesuai sehingga memudahkan orang lain memahami gagasan yang ingin disampaikan.

Pembelajaran Bahasa Indonesia berbasis teks bagi guru bahasa Indonesia merupakan suatu hal yang baru. Tidak sedikit guru yang merasa kebingungan ketika mengajarkan mata pelajaran Bahasa Indonesia dengan pendekatan berbasis teks seperti yang dipaparkan di atas. Untuk memberikan pencerahan kepada guru Bahasa Indonesia pada umumnya dan siswa khususnya, perlu diadakan pengabdian masyarakat yang dapat membantu guru dan siswa semakin memahami konsep pembelajaran bahasa Indonesia berbasis teks.

Pengabdian masyarakat yang akan dilaksanakan oleh tim pengabdian dari program studi Pendidikan Bahasa dan Sastra Indonesia, FKIP, UMS merupakan kegiatan rutin yang dilaksanakan sejak 1990. Topiktopik yang dipilih untuk dijadikan sebagai bahan yang akan disampaikan melalui siaran disesuaikan dengan kebutuhan masyarakat dan sesuai dengan perkembangan informasi dan isu-isu di masyarakat.

Pembelajaran Bahasa Indonesia berbasis teks merupakan hal baru bagi guru dan siswa yang mengajar dan belajar bahasa Indonesia. Perubahan paradigma pembelajaran yang terjadi berdampak pada meningkatnya kebutuhan masyarakat, khususnya guru dan siswa untuk memahami dan mampu mengikuti perubahan tersebut. Belum tersedianya referensi yang memadai berkaitan dengan pembelajaran berbasis teks menjadi kendala dalam penerapan pembelajaran Bahasa Indonesia.

Dosen program studi Pendidikan Bahasa dan Sastra Indonesia sebagai ilmuwan bahasa mempunyai tanggung jawab untuk mencerahkan dan memahamkan guru dan siswa terkait dengan pembelajaran bahasa Indonesia berbasis teks. Hasil-hasil penelitian yang terkait dengan pembelajaran bahasa Indonesia yang relevan dengan paradigma kurikulum 2013 yang berbasis teks dapat dijadikan sebagai materi siaran di RRI Surakarta.

Pembelajaran Bahasa Indonesia berbasis teks dilaksanakan dengan prinsip bahwa: (1) bahasa hendaknya dipandang sebagai teks, bukan semata-mata kumpulan kata-kata atau kaidah-kaidah kebahasaan; (2) penggunaan bahasa melalui proses pemilihan bentuk-bentuk kebahasaan untuk mengungkapkan makna; (3) bahasa bersifat fungsional, yaitu penggunaan bahasa yang tidak pernah dapat dilepaskan dari konteks 
karena dalam bentuk bahasa yang digunakan itu tercermin ide, sikap, nilai, dan ideologi penggunanya; dan (4) bahasa merupakan sarana pembentukan kemampuan berpikir manusia. Sehubungan dengan prinsip-prinsip itu, perlu disadari bahwa di dalam setiap teks terdapat struktur tersendiri satu sama lain berbeda. Sementara itu, dalam struktur teks tercermin struktur berpikir. Dengan demikian, semakin banyak jenis teks yang dikuasai siswa, semakin banyak pula struktur berpikir yang dapat digunakannya dalam kehidupan sosial dan akademiknya nanti. Hanya dengan cara itu, siswa kemudian dapat mengonstruksi ilmu pengetahuannya melalui kemampuan mengobservasi, mempertanyakan, mengasosiasikan, menganalisis, dan menyajikan hasil analisis secara memadai (Kemdikbud, 2013:iv-v).

Teks dpaat diperinci ke dalam beberapa jenis, di antaranya deskripsi, penceritaan (recount), prosedur, laporan, eksplanasi, eksposisi, diskusi, surat, iklan, cacatan harian, negosiasi, pantun, dongeng, anekdot, dan fiksi sejarah. Semua jenis teks itu dapat dikelompokkan ke dalam teks cerita, teks faktual, dan teks tanggapan. Teks faktual dan teks tanggapan merupakan teks nonsastra yang masing-masing dapat dibagi lebih lanjut menjadi teks laporan dan teks prosedural serta teks transaksional dan teks ekspositori. Sementara itu, teks cerita merupakan jenis teks sastra yang dapat diperinci menjadi teks cerita naratif dan teks cerita nonnaratif.

Jenis-jenis teks itu dapat dibedakan atas dasar tujuan (yang tidak lain adalah fungsi sosial teks), struktur teks (taaaaaata organisasi), dan ciri-ciri kebahasaan teks-teks tersebut. Sesuai dengan prinsip teks tersebut, teks yang berbeda tentu memiliki fungsi yang berbeda, struktur teks berbeda, dan ciri-ciri kebahasaan yang berbeda. Dengan demikian pembelajaran bahasa yang berbasis teks merupakan pembelajaran yang memungkinkan siswa untuk menguasai dan menggunakan jenis-jenis teks tersebut di masyarakat.

Tujuan pengabdian masyarakat ini sebagai berikut.

1. Meningkatkan pemahaman guru Bahasa Indonesia tentang pembelajaran Bahasa Indonesia berbasis teks.

2. Memperluas wawasan para pendengar, khususnya para pelajar tentang pembelajaran bahasa Indonesia berdasarkan kurikulum 2013.

3. Menjalin kerjasama kelembagaan antara Universitas Muhammadiyah Surakarta dengan lembaga pemerintah dalam hal ini Radio republik Indonesia Surakarta.

Manfaat yang dapat dipetik dari kegiatan pengabdian masyarakat ini antara lain:

1. terjalinnya hubungan yang harmonis antar Universitas Muham- madiyah Surakarta dengan instansi pemerintah (Radio Repub- lik Indonesia Cabang Muda Surakarta);

2. meningkatnya pemahaman guru tentang pembelajaran bahasa Indonesia berbasis teks.

3. dosen-dosen program studi Pendidikan Bahasa dan Sastra Indonesia, FKIP UMS dapat meyumbangkan dan mengembangkan ilmunya melalui kegiatan ini.

\section{METODE KEGIATAN}

Pengabdian masyarakat ini dilaksanakan di RRI Surakarta, dalam bentuk ceramah dalam siaran, berdasarkan pada makalah yang sudah dipersiapkan sebelumnya. Kegiatan siaran tersebut dilakukan dengan rekaman sebelum disiarkan. Rekaman memanfaatkan fasilitas di RRI Surakarta dengan dipandu oleh karyawan di RRI Surakarta, baik penanggung jawab maupun bagian rekaman. 


\section{HASIL DAN PEMBAHASAN}

Kegiatan ini dilaksanakan dengan ceramah dalam siaran yang setiap kali diisi oleh seorang penceramah dengan topik yang bervariasi tetapi masih dalam satu tema. Tema siaran pada triwulan ini adalah "Peningkatan Pemahaman Pembelajaran Bahasa Indonesia Berbasis Teks dalam Kurikulum 2013 melalui Siaran Pembinaan Bahasa Indonesia di RRI Surakarta". Keenam kali kegiatan siaran yang direncanakan selama tiga bulan dapat terlaksana enam kali siaran baru. Keenam siaran baru tersebut yaitu: (1) Pembelajaran Berbasis Teks Terjemahan Alquran (1); (2) Pembelajaran Berbasis Teks Terjemahan Alquran (2); (3) Teks Sastra dalam Kurikulum 2013; (4) Peningkatan Kuantitas Pembelajaran Teks Sastra; (5) Berbahasa Indonesia yang Baik dan Benar; dan (6) Pembelajaran Paragraf Berbasis Teks.

Topik pertama memaparkan tentang prinsip pembelajaran bahasa Indonesia berbasis teks dinyatakan berikut: (1) bahasa hendaknya dipandang sebagai teks, bukan semata-mata kumpulan kata-kata atau kaidah-kaidah kebahasaan, (2) penggunaan bahasa merupakan proses pemilihan bentukbentuk kebahasaan untuk mengungkapkan makna, (3) bahasa bersifat fungsional, yaitu penggunaan bahasa yang tidak pernah dapat dilepaskan dari konteks karena dalam bentuk bahasa yang digunakan itu tercermin ide, sikap, nilai, dan ideologi penggunanya, dan (4) Bahasa merupakan sarana pembentukan kemampuan berpikir manusia.

Berdasarkan prinsip itu, terdapat asumsi yang mendasarinya. Asumsinya di dalam setiap teks terdapat struktur tersendiri yang satu sama lain berbeda, dalam struktur teks tercermin struktur berpikir, makin banyak jenis teks yang dikuasai siswa, makin banyak pula struktur berpikir yang dapat digunakannya dalam kehidupan sosial dan akademiknya, dengan cara itu, siswa kemudian dapat mengonstruksi ilmu pengetahuannya melalui kemampuan mengobservasi, mempertanyakan, mengasosiasikan, menganalisis, dan menyajikan hasil analisis secara memadai.

Pembelajaran berbasis teks terjemahan Alquran, khususnya, tranformasi fokus pada teks terjemahan. Pembelajaran ini diawali dengan penyusunan materi ajar yang berbasis pada penelitian terhadap teks terjemahan Alquran. Teks terjemahan Alquran yang dimaksud di sini adalah teks terjemahan Alquran dari Bahasa Arab ke dalam Bahasa Indonesia. Jadi, yang diteliti adalah teks terjemahan dalam bahasa Indonesia. Dari hasil penelitian itu kemudian dikembangkan menjadi materi ajar berbasis teks terjemahan Alquran. Pemilihan materi ajar ini didasari oleh kenyataan bahwa teks terjemahan Alquran merupakan salah satu fenomena penggunaan bahasa Indonesia. Sebagai salah satu fenomena penggunaan bahasa Indonesia atau salah satu teks dalam bahasa Indonesia sudah selayaknya untuk mendapat perhatian dalam pembelajaran. Kalimat-kalimat yang ada pada teks terjemahan Alquran itu perlu mendapat perhatian dan menjadi bahan yang layak untuk dianalisis.

Pelaksanaan pembelajaran secara prosedural tidak jauh berbeda dengan pembelajaran pada materi ajar yang lain. Hal yang membedakannya dengan pembelajaran yang lain adalah perbedaan pada materi ajar yang dibahas. Artinya, secara prosedural pembelajaran terdiri atas tiga kegiatan besar, yakni pembukaan, inti, dan penutup. Pembelajaran dilakukan dengan kegiatan: membuka pelajaran, berdoa dengan membaca umul kita dan doa belajar, memberi motivasi, mengaitkan materi ajar yang disampaikan dengan materi ajar yang telah disampaikan pada pertemuan yang sebelumnya, yakni transformasi fokus. Setelah itu pembelajaran dilanjutkan dengan 
menyampaikan kompetensi dasar yang akan dicapai.

Topik kedua memaparkan tentang penanda fokus -lah/pun, dan penggunaan posesif -nya. Pemberian fokus dengan penanda -lah dan pun terdapat pada fungsi Subjek, Predikat, dan pada pemadu kalimat yang lain.

Pemberian fokus dengan penanadalah/pun pada Subjek, sering diikuti tekanan dan diikuti dengan partikel yang misalnya, contoh (23/18) "Dialah yang lebih mengetahui...” terdapat partikel -lah dan yang. Penggunaan partikel -pun sebagai penanda fokus terdapat pada contoh (22/17).

a. Partikel -lah/pun pada Subjek

(17) tidak ada satu jiwa pun akan beriman kecuali dengan izin Allah. (Yunus (10) : 99-100)

(18) Dialah yang lebih mengetahui orang-orang yang mendapat petunjuk. (An-Nahl (16): 12)

Pada kalimat/klausa (17) terdapat penanda pun sebagai penanda fokus, sedangkan pada kalimat (18) terdapat penanda-lah yang.

b. Partikel -lah pada Predikat

Penggunaan partikel -lah juga terdapat pada predikat, seperti pada kalimat (22).

(22) Kami mendengar dan patuh, dan dengarlah, dan perhatikannlah kami; tentulah itu baik bagi mereka (An-Nisaa' (4): 46).

c. Partikel - lah pada Pemadu Kalimat Lain Pada contoh berikut pemberian fokus dengan penanda -lah diberikan pada $\mathrm{K}$.

(23) Kepada Tuhan merekalah kembali mereka. (Al-An'aam (6): 108)

(24) Kepada-Nyalah naik perkataanperkataan yang baik dan amal yang saleh dinaikkannya. (Faathir (35): 10)

Pengunaan partikel -lah pada pemadu kalimat lain pada dasarnya prinsipnya sama dengan penggunaan penanda-lah pada $\mathrm{S}$ dan P. Artinya, K (keterangan) yang mendapat partikel -lah, berarti fokus itu diberikan pada $\mathrm{K}$. Hal yang dipentingkan dalam kalimat itu adalah K.

\section{Penanda Fokus Berupa Penggunaan Posesif-nya}

Penanda fokus yang berupa penggunaan posesif -nya dipakai oleh pemakai bahasa Indonesia jika pemakai tersebut akan memberikan fokus pada pemadu kalimat yang ingin ditekankan. Posesif adalah penanda yang menyatakan milik.

(25) ibunya mengandungnya dengan susah payah (pula)

(Al-Akhqaf (46): 15)

Pada contoh (25) pemberian fokus dilakukan pada $S$ dengan memberikan posesif -nya. Jika contoh (25) tersebut tidak diberi penanda fokus -nya, tampak seperti (25a).

(25a) ibu mengandung dengan susah payah (pula)

Pendengar yang saya hormati,

\section{Implikasi Pemberian Fokus}

Pada umumnya pemberian fokus dimaksudkan untuk memberikan penekanan atau penguatan pada unsur kalimat tertentu. a. Penguatan pada $S$

Pemberian fokus pada contoh (27) adalah bahwa tidak ada yang Maha mengetahui dan tidak ada yang maha Bijaksana selain Allah. Implikasi ini sama dengan tidak ada manusia atau makhluk yang ada di bumi ini yang bisa menyamai kebijakasanaan dan pengetahuan Allah. Implikasinya adalah penguatan pada $S$. 
(27)

Sesungguhnya Engkaulah yang Maha mengetahui lagi Maha

Bijaksana.(Al-Baqarah (2): 31 32).

b. Penguatan terhadap jawaban pertanyaan Pengedepanan keterangan waktu pada dat (28) menerangkan bahwasannya Allah telah memberi penjelasan tentang sapi betina yang ditanyakan Bani Israil kepada Nabi Musa. Implikasi yang dapat diambil dari penggalan terjemahan surat ini adalah Allah Maha pengasih dan Maha penyayang, yakni dengan memberikan jawaban terhadap pertanyaan, siapa pun yang menyanyakan pertanyaan itu. Implikasi ini berupa penguatan terhadap jawaban pertanyaan. (28) Sekarang barulah kamu menerangkan hakikat sapi betina yang sebenarnya. (Al-Baqarah (2): 71).

c. Penguatan pada keserba-Mahaan Allah

Allah Maha pengasih, penyayang, melihat, mengetahui, dan berbagai sifat lainnya. Tidak ada makhluk lain yang bisa menyamainya. Kelebihan itu sifat keserba-Mahaan Allah.

(29) di antara manusia ada orang yang ucapannya tentang kehidupan dunia menarik hatimu. dipersaksikannya kepada Allah (atas kebenaran) isi hatinya. (AlBaqarah (2): 204)

Pengedepanan kata dipersaksikannya ini untuk menjelaskan bahwa ada proses di dalamnya, yaitu perbuatan untuk memperlihatkan isi hatinya kepada Allah. Implikasi yang dapat terbaca pada contoh (29) adalah Allah Maha mengetahui atas segalanya, termasuk apa yang disembunyikan manusia di dalam hatinya. Jadi, kita tidak boleh memiliki niat yang buruk karena Allah pasti mengetahuinya. Implikasi ini dapat dikelompokkan pada keserba-Mahaan Allah.

\section{d. Penguatan pada verba}

Penguatan terhadap verba ini dapat berupa verba larangan dan verba perintah. Verba larangan di antaranya larangnan: memusuhi nabi, menyekutukan Allah, memakan harta anak yatim, mempercayai orang kafir dan fasik, memendam perasaan dengki, berkata kotor, berprasangka buruk, meremehkan keterangan dari Allah, menolak kebenaran, menerima berita dari orang fasik, dan larangan sembarangan atau ceplasceplos dalam bertutur. Pada kesempatan ini tidak semua contoh ditampilkan. Berikut adalah contoh verba larangan.

Pengedepanan verba perintah mengutamakan perintah untuk memberikan harta kepada orang-orang yang sudah sempurna akalnya. Jadi, implikasinya adalah kita tidak boleh memakan harta orang lain, apalagi anak yatim piatu.

(30) Berilah mereka belanja. (AnNissa' (4):5)

(31) sederhanakanlah kamu dalam berjalan. (Al-Lukman (31): 19)

Pemberian fokus pada contoh (30) ini dimaksudkan untuk mengedepankan perintah untuk sederhana, baik berjalan maupun dalam bertutur. Jadi, implikasinya adalah kita tidak boleh sombong atau kasar.

Penguatan terhadap verba yang menyatakan perintah ditemukan beberapa jenis perintah, yakni perintah untuk: memiliki sifat pemaaf, yakin terhadap ketetapan Allah, beriman dan bertaqwa kepada Allah dengan sungguh-sungguh, menganggap baik terhadap Allah, memberikan harta anak yatim yang sudah sempurna akalnya. Pada kesemptan ini hanya dinyatakan beberapa contoh contoh yang berimplikasi perintah 
(32) Demikianlah Kami perindah bagi setiap umat mereka. (Al-An'aam (6): 108)

Kita diperintah untuk menganggap baik terhadap Allah karena Allah telah membuat semua indah (contoh 32).

(33) Kami beriman kepada yang sebagian. (An-Nisaa' (4): 150)

Pemadu kalimat yang mendapat fokus itu, yakni beriman yang secara implisit dipertentangkan dengan verba lainnya, misalnya kafir, khufur, dsb. Mereka, S dalam contoh (33), memilah-milah keimanannya sesuai dengan kesenangan hati mereka. Jadi, mereka hanya mengimani sebagian saja (tidak utuh, tidak lengkap). Jadi, implikasi pemberian fokus itu kita diperintah untuk beriman dengan sungguh-sungguh dan menyeluruh (utuh).

Topik ketiga membahas tentang teks sastra dalam Kurikulum 2013 Keberadaan pembelajaran sastra selama ini sering dipermasalahkan, bahkan sering terjadi pendapat yang pro dan kontra. Pendapat yang pro menganggap pembelajaran sastra sangat penting dalam rangka ikut membentuk watak siswa, supaya siswa berkarakter, berbudi pekerti yang luhur, berwawasan luas, mampu mengembangkan berbagai keterampilan berbahasa, dan seterusnya. Namun, terdapat juga pendapat yang kontra yang menganggap bahwa sastra tidak penting karena yang dipelajari adalah hasil imajinasi yang tidak ada kaitannya dengan dunia nyata. Mereka menganggap mempelajari karya sastra hanya membuang-buang waktu, menghabiskan energi, dan tidak bisa dijadikan alat untuk menghadapi masa depan.

Dalam kehidupan, kebutuhan akan teks sastra dalam masyarakat cukup tinggi. Banyaknya media massa, baik cetak maupun elektronik membutuhkan karya sastra. Surat kabar harian pada hari tertentu selalu memuat puisi dan cerpen, bahkan cerita bersambung. Begitu pula, televisi dengan berbagai siaran sinetron atau film membutuhkan karya sastra yang berupa skenario atau naskah drama. Begitu pula, dalam perayaan-perayaan di masyarakat juga masih ditemukan pentaspentas yang membutuhkan naskah drama. Penulisan dan pembacaan puisi maupun cerpen juga masih sering dilombakan untuk memeriahkan acara-acara tertentu. Oleh karena itu, keberadaan pembelajaran sastra masih dianggap penting.

Jika dilihat dari persentase kehadiran pembelajaran teks sastra jika dibandingkan dengan teks nonsastra dalam mata pelajaran Bahasa Indonesia, teks sastra dalam kurikulum 2013 memiliki prosentase yang sedikit, yaitu: di SD teks sastra sebesar $28 \%$, pada jenjang SMP/MTs. sebanyak 23\%, dan SMA/MA sebanyak 43\%. Ini menunjukkan bahwa berdasarkan kurikulum 2013 ini pembelajaran sastra memiliki prosentase yang sedikit. Oleh karena itu, Bapak Ibu guru di sekolah perlu mengintensifkan pembelajaran sastra yang porsinya sudah sedikit ini agar sastra masih menjadi pembelajaran yang menyenangkan dan bermakna. Hadirkan karya sastra yang bermutu dan diapresiasi oleh anak-anak dengan intensif. Karya sastra perlu dibaca, baik pembacaan dalam hati maupun pembacaan nyaring, dipahami maknanya, diinterpretasikan sesuai dengan kemampuan anak-anak, dan diambil manfaatnya untuk diterapkan dalam kehidupan sehari-hari.

Topik keempat berbicara tentang peningkatan kuantitas pembelajaran teks sastra Teks-teks sastra yang di dalam kurikulum 2013 tidak dicantumkan sebagai bahan ajar, perlu diajarkan kepada siswa, tentu saja dengan cara dan strategi yang kreatif. Misalnya, karya sastra disisipkan dalam pembelajaran teks nonsastra dalam mata pelajaran Bahasa Indonesia. Salah satu contoh pembelajaran yang menyisipkan teks sastra dalam pembelajaran teks nonsastra adalah memulai pembelajaran dengan 
membaca teks sastra. Hal ini bisa dimaksudkan untuk membangun konteks atau menekankan tema pembelajaran yang sedang berlangsung. Misalnya, pembelajaran teks deskriptif dengan tema lingkungan hidup. Pembelajaran ini memang bukan pembelajaran teks sastra, tetapi bisa dimulai dengan menghadirkan teks sastra untuk memulai pembelajaran. Salah satu contoh: kegiatan membaca puisi yang isinya mendeskripsikan lingkungan hidup. Berangkat dari pembacaan puisi inilah guru dan siswa selanjutnya mempelajari teks deskriptif. Saya percaya, cara ini tidak akan mengganggu efektifitas pencapaian pembelajaran teks lain. Justru sebaliknya, siswa akan memulai pembelajaran dengan menyenangkan, memahami tema pembelajaran yang akan berlangsung, dan mulai memahami hakikat isi teks deskriptif. Tentu saja, hal ini membutuhkan guru yang kreatif.

Topik kelima berbicara tentang berbahasa Indonesia yang baik dan benar. Bahasa Indonesia merupakan salah satu hasil budaya bangsa Indonesia sebagai bagian dari anugerah ciptaan Allah swt. Hakikat bahasa Indonesia menurut kesepakatan pengakuan para ahli terdahulu, bahasa Indonesia berakar dari bahasa Melayu (Riau) yang berkembang bersama masuknya unsur bahasa daerah dan bahasa asing.

Terkait dengan perkembangan teknologi pada saat guru dan peserta didik membicarakan telepon genggam atau hand phone (HP), yang dominan disebut adalah HP. Ketika menyebut pelayanan pesan singkat atau SMS, maka yang dominan adalah menyebut sms. Begitu juga penyebutan tidak disuarakan atau disilent. Kata-kata, frasa dari bahasa daerah atau bahasa asing yang umum atau dominan sebaiknya oleh yang berwenang diintegrasikan ke dalam bahasa Indonesia (diindonesiakan). Hal ini merupakan langkah untuk mengembangkan bahasa Indonesia, sekaligus merupakan upaya penggunaan bahasa Indonesia yang baik dan benar sesuai konteksnya.

Topik keenam memaparkan tentang pembelajaran paragraf berbasis teks. Paragraf atau alinea adalah rangkaian kalimat yang saling berhubungan (koheren) dan membentuk sebuah ide. Rangkaian kalimat yang dimaksudkan terdiri dari satu kalimat topik dan dua sampai dengan enam kalimat penjelas. Dilihat dari bentuk atau model pencetakannya di Indonesia pada umumnya menggunakan bentuk atau model resmi yang juga lazim disebut model Indonesia. Sementara yang lain sedikit ada yang menggunakan bentuk lurus. Kerangka berpikir yang dipergunakan ada yang deduktif dan sebaliknya yakni induktif. Berbasis teks di sini, dimaksudkan pembelajaran yang dipandu dengan bacaan baik teks ilmiah, berita dalam media cetak, maupun sastra.

Adapun hasil evaluasi terhadap kegiatan pengabdian masyarakat ini dipaparkan sebagai berikut. Sempitnya waktu yang tersedia untuk siaran (kurang lebih 20 menit) menyebabkan topik yang kami sajikan kurang dapat dibahas secara mendalam. Topik-topik yang disampaikan alam siaran ini dirasa hanya sebagai pengantar dan kurang analisis.

Perhatian masyarakat terhadap radio relatif kecil jika dibandingkan dengan perhatian masyarakat terhadap siaran televisi. Hal ini berdampak pada kurang tersampaikannya materi-materi yang disiarkan kepada masyarakat.

Fasilitas siaran cukup memadai telah disediakan oleh RRI Surakarta. Pelayanan karyawan pada saat kami rekaman sangat membantu kelancaran kami dalam melaksanakan pengabdian masyarakat ini.

Waktu yang disediakan oleh RRI untuk siaran cukup bagus yaitu pukul 19.20 
s.d. 19.40 WIB. Saat seperti ini merupakan waktu istirahat bagi masyarakat sehingga memungkinkan masyarakat mendengarkan siaran radio.

Bagi dosen-dosen Program Studi Pendidikan Bahasa dan Sastra Indonesia FKIP UMS kegiatan ini sudah bukan menjadi kegiatan yang perlu disiapkan dengan mencurahkan banyak waktu dan energi, karena kegiatan ini sudah dilaksanakan secara rutin selama bertahun-tahun. Dengan demikian, keberlangsungan kegiatan ini tidak perlu dikhawatirkan.

Pengabdian masyarakat ini berjalan lancar. Enam kali siaran yang kami rencanakan dapat dilaksanakan dengan enam kali siaran baru. Dari segi pendengar, kami belum dapat melaporkan sejauh mana dampak siaran kami terhadap pendengar, baik pendengar pada umumnya maupun para pelajar pada khususnya. Kami belum mengadakan penelitian khusus mengenai hal ini.

\section{SIMPULAN DAN SARAN}

\section{Simpulan}

Pengabdian masyarakat yang dilaksanakan oleh dosen-dosen pada Program studi PBSI FKIP UMS berupa penyuluhan tentang pemakaian bahasa Indonesia yang baik dan benar, dengan topik yang bervariasi. Topik pada triwulan ini adalah "Peningkatan Pemahaman Pembelajaran Bahasa Indonesia Berbasis Teks dalam Kurikulum 2013 melalui Siaran Pembinaan Bahasa Indonesia di RRI Surakarta". Keenam kali kegiatan siaran yang direncanakan selama tiga bulan dapat terlaksana enam kali siaran baru. Keenam siaran baru tersebut yaitu: (1) Pembelajaran Berbasis Teks Terjemahan Alquran (1); (2) Pembelajaran Berbasis Teks Terjemahan Alquran (2); (3) Teks Sastra dalam Kurikulum 2013; (4) Peningkatan Kuantitas Pembelajaran Teks Sastra; (5) Berbahasa Indonesia yang Baik dan Benar; dan (6) Pembelajaran Paragraf Berbasis Teks. Pengabdian masyarakat yang kami lakukan pada bulan Oktober, November, dan Desember 2014 dapat berjalan dengan baik.

\section{Saran}

Alangkah baiknya, pengabdian masyarakat ini terus ditingkatkan kualitasnya. Pelaksanaannya bisa dilakukan secara bervariasi, baik variasi topik maupun cara siarannya. Kalau selama ini, siaran cenderung dilakukan secara rekaman dengan seorang penceramah, dengan topik-topik yang bervariasi, selanjutnya diusulkan dengan dialog interaktif atau tim dengan tanya jawab.

\section{DAFTAR PUSTAKA}

Kemdikbud. 2013. Bahasa Indonesia Wahana Pengetahuan. Kendikbud: Jakarta. 